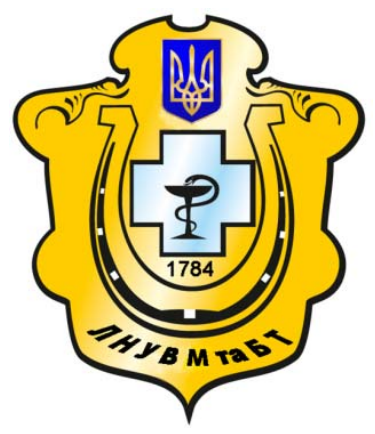

Науковий вісник Львівського національного університету ветеринарної медицини та біотехнологій імені С.3. Гжицького

Scientific Messenger of Lviv National University of Veterinary Medicine and Biotechnologies named after S.Z. Gzhytskyj

doi:10.15421/nvlvet7306

ISSN 2518-7554 print

ISSN 2518-1327 online

$\underline{\text { http://nvlvet.com.ua/ }}$

УДК 619:636.22/.28.4

\title{
Проблемні питання адаптації корів голштинської породи в умовах промислової технології виробництва молока
}

\author{
Р.В. Милостивий, О.О. Калиниченко, Т.О. Василенко, Д.Ф. Милостива, А.С. Гуцуляк \\ roma_vet@i.ua
}

Дніпропетровський державний аграрно-економічний університет, вул. Ворочилова, 25, м. Дніпро, 49600, Україна

\begin{abstract}
Проведено аналіз довічної продуктивності корів голштинської породи європейської селекції та їх дочок за промислової технології виробництва молока, з'ясовані причини вибракування тварин внаслідок захворювань. Встановлено, що в умовах промислового комплексу різко знижується термін продуктивного використання голитинської худоби. Тривалість лактаційного періоду в корів-дочок порівнянні з матерями достовірно скоротилася на 463,6 дні (на 32,5\%) і склала лише 2,5 лактаиії (P < 0,01). При иъьому довічний надій виявився нижчим на 8427,1 к2 (25,9\%), а упродовж життя від них було отримано на одне теля менше.

Основними причинами передчасного вибуття із стада імпортних тварин були порушення відтворювальної здатності $(25,6 \%)$ і післяродові ускладнення (7,4\%), хвороби органів травлення $(22,3 \%)$, кінцівок $(21,5 \%)$ і мастити (6,6\%). Надмірна експлуатація тварин призвела до зниження природної резистентності, що проявилося в зростанні серед корів першої генерації патології репродуктивних органів (6,7\%), органів травлення (5,5\%) і молочної залози (8,5\%).

Прискорений оборот стада внаслідок передчасного вибуття високопродуктивних корів зумовлює необхідність пошуку раціональних шляхів підвищення природної резистентності організму тварин за промислової технологї̈ виробництва молока спрямованих на подовження їхнього продуктивного довголіття.

Ключові слова: адаптачия, голитинська порода, промислова технологія, тривалість господарського використання, довічна продуктивність, причини вибракування корів.
\end{abstract}

\section{Проблемные вопросы адаптации коров голштинской породы в условиях промышленной технологии производства молока}

\author{
Р.В. Милостивый, А.А. Калиниченко, Т.О. Василенко, Д.Ф. Милостива, А.С. Гуцуляк \\ roma_vet@i.ua
}

Днепропетровский государственный аграрно-экономический университет, ул. Ворочилова, 25, г. Днепр, 49600, Украина

\begin{abstract}
Проведен анализ пожизненной продуктивности коров голштинской породы европейской селекции и их дочерей в условиях промышленной технологии производства молока, выяснены причины выбраковки животных вследствие заболеваний. Установлено, что в условиях промышленного комплекса резко снижается срок продуктивного использования голитинского скота. Продолжительность лактаиионного периода у коров-дочерей по сравнению с матерями достоверно сократилась на 463,6 дня (на 32,5\%) и составила всего 2,5 лактации (P <0,01). При этом пожизненный удой оказался ниже на 8427,1 кг (25,9\%), а в течение жизни от них было получено на одного теленка меньше.

Основными причинами преждевременного выбытия из стада импортных животных были: нарушение воспроизводительной способности (25,6\%) и послеродовые осложнения (7,4\%), болезни органов пищеварения (22,3\%), конечностей (21,5\%) и маститы (6,6\%). Чрезмерная эксплуатация животных привела к снижению естественной резистентности, что прояви-
\end{abstract}

\section{Citation:}

Milostiviy, R.V., Kalinichenko, O.O., Vasilenko, T.O., Milostiva, D.F., Gutsulyak, G.S. (2017). Problematic issues of adaptation of cows of golshtinskaya breed in the conditions of industrial technology of milk production. Scientific Messenger LNUVMBT named after S.Z. Gzhytskyj, 19(73), 2832 . 
лось в увеличении среди коров первого поколения патологии репродуктивных органов (6,7\%), органов пищеварения (5,5\%) и молочной железы $(8,5 \%)$.

Ускоренный оборот стада в результате преждевременного выбытия высокопродуктивных коров, обусловливает необходимость поиска рациональных путей повышения естественной резистентности организма животных в условиях промышленной технологии производства молока направленных на продление их продуктивного долголетия.

Ключевые слова: адаптация, голштинская порода, промышленная технология, продолжительность хозяйственного использования, пожизненная продуктивность, причины выбраковки коров.

\title{
Problematic issues of adaptation of cows of golshtinskaya breed in the conditions of industrial technology of milk production
}

\author{
R.V. Milostiviy, O.O. Kalinichenko, T.O. Vasilenko, D.F. Milostiva, G.S. Gutsulyak \\ roma_vet@i.ua
}

Dnepropetrovsk state agrarian-economic university, Voroshilov Str., 25, Dnepr, 49600, Ukraine

\begin{abstract}
The increase in the duration of productive longevity of highly productive cows remains a problematic issue and in recent years has attracted increasing attention of domestic and foreign scientists. Accelerated herd turnover and significant premature retirement of Holstein animals in herds may subsequently have negative economic and biological consequences.

The analysis of the lifetime productivity of the Holstein cattle of European breeding and their daughters under the conditions of industrial milk production technology has been carried out; the reasons for the culling of animals due to diseases have been clarified. It is established that under the conditions of an industrial complex the period of productive use of Holstein cattle is sharply reduced. The duration of the lactation period in cows-daughters compared with mothers significantly decreased by 463.6 days (by $32.5 \%)$ and amounted to only 2.5 lactations $(P<0.01)$. At the same time, lifelong milk yield was lower by $8427.1 \mathrm{~kg}(25.9 \%)$, and during life from them was received on one calf less.

The main reasons for premature departure from the herd of imported animals were: a violation of reproductive capacity (25.6\%) and postpartum complications $(7.4 \%)$, diseases of the digestive system (22.3\%), limbs (21.5\%) and mastitis (6.6\%). Excessive exploitation of animals led to a decrease in natural resistance, which manifested itself in an increase in the number of pathologies of reproductive organs (6.7\%), digestive organs (5.5\%) and mammary glands $(8.5 \%)$ among the first-generation cows.

Accelerated herd turnover as a result of premature retirement of highly productive cows, necessitates the search for rational ways to increase the natural resistance of the animal organism in conditions of industrial milk production technology aimed at prolonging their productive longevity.
\end{abstract}

Key words: adaptation, Holstein breed, industrial technology, duration of economic use, lifelong productivity, causes of cows culling.

\section{Вступ}

Подовження тривалості продуктивного довголіття високопродуктивних корів залишається проблемним питанням і в останні роки привертає все більшу увагу вітчизняних та зарубіжних вчених (Sewalem et al., 2008; Vysokos et al., 2014; Karatieieva and Bezbabna, 2014; Mylostyvyi et al., 2016; Hmel'nichij and Vechjorka, 2016; Oleshko, 2016; Khmelnychyi and Vechorka, 2016; Compton et al., 2016). Прискорений оборот стада і значне передчасне вибракування тварин голштинської породи іноземної і вітчизняної селекції в господарствах країни можуть мати в подальшому негативні як економічні, так і біологічні наслідки (Van Raden and Wiggans, 1995; Van Raden, 2004; Vysokos et al., 2014).

Висвітленню даної проблеми присвячено багато наукових праць, проте чимало аспектів наразі залишаються ще недостатньо розкритими і визначеними. Зустрічаються доволі суперечливі дані стосовно вибуття корів з причини їхньої захворюваності, про зростання якої в останні десятиліття повідомляють окремі дослідники (Murray, 2013). Зокрема серед основних причин вибракування корів у країнах з розвинутим молочним скотарством $€$ патологія органів розмноження (особливо пов'язана 3 післяродовими ускладненнями), молочної залози та кінцівок (у т.ч. травми), на відсоткове співвідношення прояву яких у стаді істотно впливає чисельність поголів'я й умови експлуатації тварин. Водночас значна частина причин вибуття зі стада молочних корів (від 15 до 40\%) залишається невідомою, що може істотно впливати на 3'ясування їх генезу і розробку адекватних превентивних заходів (Endres, 2008; Murray, 2013; Nayeri et al., 2016). Це зумовлює актуальність проведення подальших досліджень щодо вивчення причин передчасного вибуття високопродуктивних молочних корів та пошуку раціональних шляхів подовження продуктивного довголіття тварин (Puhach et al., 2014; Milostivyj et al., 2016; Oleshko, 2016; Puhach et al., 2016; Nayeri et al., 2016; Chebel et al., 2016).

Метою досліджень була оцінка довічної продуктивності корів голштинської породи європейської селекції та їх дочок за довічним надоєм в умовах промислового комплексу та з'ясувати причини передчасного вибуття зі стада тварин.

\section{Матеріал та методи досліджень}

Дослідження проведені в умовах ПрАТ «АгроСоюз» Дніпропетровської області на поголів'ї, які вибули зі стада імпортних корів голштинської породи європейської селекції за даними первинного обліку господарства в системі «Орсек». Репрезентативним 
методом з числа корів із закінченою лактацією було сформовано дослідні групи тварин: перша - імпортні тварини (з Німеччини і Даніі), завезені в господарство нетелями, та друга - їхні корови-дочки першої генерації. При цьому враховували тривалість лактаційного періоду, довічний надій, кількість лактацій, середній надій за лактацію, кількість жиру в молоці, кількість одержаних від корів телят. Тварин утримували безприв'язним способом у боксах сучасного корівника полегшеного типу. Рівень годівлі корів відповідав вимогам годівлі молочних корів різного фізіологічного стану, однотипні кормові суміші раціону були збалансовані за основними поживними та мінеральними речовинами.

Біометричну обробку даних здійснювали за допомогою програмного забезпечення MS Excel з використанням вбудованих статистичних функцій. Вірогід- ність різниці середніх показників визначали за критерієм Ст'юдента.

\section{Результати та їх обговорення}

В результаті проведених досліджень було встановлено, що в умовах промислового комплексу при інтенсивній експлуатації корів різко знижується термін використання тварин (табл. 1). Так, порівняно з матерями, тривалість лактаційного періоду в дочок достовірно скоротилася на 463,6 дні (на 32,5\%) і склала лише 2,5 лактації $(\mathrm{P}<0,01)$. При цьому довічний удій на одну корову-дочку виявився нижчим на 8427,1 кг $(25,9 \%)$. Як наслідок - від корів-дочок імпортних тварин протягом життя було отримано на одне теля менше.

Довічна продуктивність корів голштинської породи (M \pm m)

\begin{tabular}{|l|c|c|}
\hline \multicolumn{2}{|c|}{ Показник } & \multicolumn{2}{|c|}{ Група тварин, $\mathrm{n}=44$} \\
\cline { 2 - 3 } & корови-матери & корови-дочки \\
\hline Довічний надій, кг & $32508,7 \pm 2185,98$ & $24081,6 \pm 2008,56^{*}$ \\
\hline Тривалість лактаційного періоду, днів & $1426,0 \pm 100,89$ & $962,4 \pm 77,68^{*}$ \\
\hline Кількість лактацій & $3,5 \pm 0,21$ & $2,5 \pm 0,19^{*}$ \\
\hline Отримано телят, голів & $4,0 \pm 0,20$ & $3,0 \pm 0,21^{*}$ \\
\hline Середньодобовий удій, кг & $22,8 \pm 0,63$ & $24,9 \pm 1,04$ \\
\hline Удій за лактацію, кг & $9288,2 \pm 322,97$ & $9632,6 \pm 404,64$ \\
\hline Кількість молочного жиру, кг & $318,9 \pm 22,47$ & $328,5 \pm 26,88$ \\
\hline
\end{tabular}

Примітки: * - вірогідність різниці між групами $\mathrm{P}<0,01$.

Така ситуація щодо зменшення продуктивності тварин, на нашу думку, певною мірою може бути обумовлена як законом регресії Ф. Гальтона, так і надмірними умовами експлуатації корів, які стали причиною високої захворюваності та передчасного вибуття зі стада (табл. 2). Встановлено, що щорічне вибракування дійних корів у господарстві перевищує 39\%. При цьому основними причинами вибуття корів стада (не враховуючи виведення зі стада тварин із низькою молочною продуктивністю та через інші невідомі причини) були порушення відтворювальної здатності і післяродові ускладнення, хвороби органів травлення, кінцівок і мастити. Необхідно відзначити, що порівняно 3 імпортними тваринами, у корів першої генерації захворювання репродуктивних органів зросли на 4,6\% (у т.ч. післяродові ускладнення - на $2,1 \%$ ). Прояв патології органів травлення зріс на 5,5\%, а молочної залози - на 8,5\%. Відсоток вибуття корів дійного стада внаслідок захворювань кінцівок зменшився, але залишався досить високим $(18,6)$. На зростання безпліддя та патології молочної залози серед поголів'я корів упродовж останніх десятиліть вказують дані інших вчених (Murray, 2013).

Основні причини вибуття корів в умовах промислового комплексу, \%

Таблиця 2

\begin{tabular}{|l|c|c|}
\hline \multicolumn{1}{|c|}{ Причина вибуття } & Імпорт & Перша генерація \\
\hline Порушення відтворювальної здатності & 25,6 & 29,0 \\
\hline Післяродові ускладнення & 7,4 & 9,5 \\
\hline Мастит & 6,6 & 15,1 \\
\hline Хвороби органів травлення & 22,3 & 27,8 \\
\hline Порушення обміну речовин & 2,5 & 2,7 \\
\hline Хвороби органів дихання & 1,4 & - \\
\hline Хвороби кінцівок & 21,5 & 18,6 \\
\hline Інші хвороби & 12,7 & 7,3 \\
\hline
\end{tabular}

Отримані нами дані щодо причин вибракування корів знаходять підтвердження в роботах зарубіжних вчених. Зокрема, як повідомляє В. Murray (Murray, 2013), ступінь вибракування в канадських молочних гуртах через порушення відтворювальної здатності сягає 30\%, за якими «йдуть» мастити і проблеми 3 кінцівками. За повідомленням M. Endres (Endres,
2008), причинами вибуття корів у молочних гуртах США були кульгавість і травми (20\%), масти (16,5\%), післяродові ускладнення (15,2\%), а за даними Franklyn B. Garry (Franklyn, 2011) відсоток вибракування через зазначену патологію становив відповідно 16,0; 23,0 та 26,3\%. Серед інших причин вибуття були хвороби органів дихання і системи травлення, відповідно 
11,3 та 10,4\%. В цілому ж серед усіх чинників вибракування корів близько 50\% пов'язані із хворобами i травмами (Franklyn, 2011).

На нашу думку поширення захворюваності серед поголів'я високопродуктивних корів в умовах надінтенсивної технології виробництва молока при безприв'язному способі утримання насамперед пов'язане зі зниженням природної резистентності й продуктивним «виснаженням» корів, а також із труднощами індивідуального контролю за клінічним станом тварин на ранніх стадіях прояву хвороб, що відображено в наших попередніх дослідженнях і підтверджується повідомленнями інших вчених (Franklyn, 2011; Karatieieva and Bezbabna, 2014; Vysokos et al., 2014; Chebel et al., 2016).

Виходячи з отриманих результатів та тривалих досліджень 3 проблемних питань адаптації тварин голштинської породи європейської селекції в умовах Придніпров'я, співробітниками кафедри технології переробки продукції тваринництва ДДАЕУ проведено ряд заходів, спрямованих на підвищення природної резистентності організму та зміцнення здоров'я корів в умовах промислового комплексу. Зокрема, для поліпшення відтворювальної здатності тварин запропоновано установку для активного моціону тварин, яка дозволяє одночасно надавати фізичні дозовані навантаження і забезпечувати природне стирання копитного рогу з підошви копит, уникаючи регулярних ортопедичних обробок кінцівок великої рогатої худоби (Puhach et al., 2014). Також нами було розроблено пристрій для зволоження та охолодження повітря в тваринницькому приміщенні 3 метою регулювання температурного режиму і підтримання відносної вологості повітря в тваринницьких приміщеннях (Puhach et al., 2016). Застосування запропонованого технічного рішення дозволить значно поліпшити умови утримання тварин при перебуванні в закритих приміщеннях в спекотні періоди року, що сприятиме підвищенню ефективності галузі молочного скотарства.

\section{Висновки}

1. В умовах промислового комплексу різко знижується термін продуктивного використання голштинської худоби. Тривалість лактаційного періоду в корів-дочок порівняно з матерями достовірно скоротилася на 463,6 дні (на 32,5\%) і склала лише 2,5 лактації $(\mathrm{P}<0,01)$. При цьому довічний надій виявився нижчим на 8427,1 кг $(25,9 \%)$, а упродовж життя від них було отримано на одне теля менше.

2. Основними причинами передчасного вибуття зі стада імпортних тварин були порушення відтворювальної здатності $(25,6 \%)$ і післяродові ускладнення $(7,4 \%)$, хвороби органів травлення $(22,3 \%)$, кінцівок $(21,5 \%)$ і мастити (6,6\%). Надмірна експлуатація тварин призвела до зниження природної резистентності, що проявилося в зростанні серед корів першої генерації патології репродуктивних органів (6,7\%), органів травлення $(5,5 \%)$ і молочної залози $(8,5 \%)$.

3. Прискорений оборот стада і передчасне вибуття високопродуктивних корів зумовлюють необхідність пошуку раціональних шляхів підвищення природної резистентності організму тварин за промислової технології виробництва молока, спрямованих на подовження їх продуктивного довголіття.

Перспективи подальших досліджень. У подальшому будуть вивчені причини поширення хвороб серед поголів'я голштинської худоби. Розроблятимуться та впроваджуватимуться заходи щодо підвищення природної резистентності організму корів в умовах промислового комплексу.

\section{Бібліографічні посилання}

Vysokos, M.P., Mylostyvyi, R.V., Tiupina, N.P. (2014). Porivnialna otsinka vplyvu tekhnolohii i system utrymannia na dovholittia produktyvnoho vykorystannia koriv holshtynskoi porody zarubizhnoi selektsii. Naukovo-tekhnichnyi biuleten NDTs biobezpeky ta ekolohichnoho kontroliu resursiv APK. Dnipropetrovsk. 2(1), 143-147 (in Ukrainian).

Karatieieva, O.I., Bezbabna, A.V. (2014). Efektyvnist tryvalosti hospodarskoho vykorystannia koriv holshtynskoi porody. Naukovyi visnyk Natsionalnoho universytetu bioresursiv i pryrodokorystuvannia Ukrainy. Seriia: Tekhnolohiia vyrobnytstva i pererobky produktsii tvarynnytstva. 202, 175-178 (in Ukrainian).

Mylostyvyi, R.V., Mylostyva, D.F., Prylutska, O.V., Vinnytskyi, V.V. (2016). Dovichna produktyvnist i vidtvorna zdatnist koriv holshtynskoi porody yevropeiskoi selektsii. Naukovo-tekhnich. biul. NDTs biobezpeky ta ekolohichnoho kontroliu resursiv APK. Dnipro. 4(4), 41-44 (in Ukrainian).

Milostivyj, R.V., Visokos, N.P., Priluckaja, E.V., Tihonenko, V.A. (2016). Meroprijatija po stabilizacii mikroklimata $\mathrm{v}$ zhivotnovodcheskih pomeshhenijah $\mathrm{v}$ zharkih pogodnyh uslovijah. Prioritetnye i innovacionnye tehnologii v zhivotnovodstve - osnova modernizacii agropromyshlennogo kompleksa Rossii: Sb. nauch. statej po materialam Mezhdunar. nauch.praktich. konf. nauchnyh sotrudnikov i prepodavatelej (16 dekabrja 2016 g.). - Stavropol', 291-295 (in Russian).

Oleshko, V.P. (2016). Efektyvnist dovichnoho vykorystannia importovanykh koriv. Rozvedennia i henetyka tvaryn. 52, 49-58 (in Ukrainian).

Puhach, A.M., Vysokos, M.P., Mylostyvyi, R.V., Tiupina, N.V., Kalynychenko, A.O. (2016). Patent na korysnu model № 108437, MPK F24F 6/12 «Prystrii dlia zvolozhennia ta okholodzhennia povitria V tvarynnytskomu prymishchenni»; Zaiavl. 26.02.16. Opubl. 11.07.2016. Biul. №13 (in Ukrainian).

Puhach, A.M., Vysokos, M.P., Tiupina, N.V. (2014). Patent na korysnu model № 90516, MPK A01K 1/00 «Ustanovka dlia aktyvnoho motsionu tvaryn»; Zaiavl. 20.01.14. Opubl. 26.05.2014. Biul. № 10 (in Ukrainian).

Polupan, Yu.P. (2014). Efektyvnist dovichnoho vykorystannia koriv riznykh krain selektsii. Visnyk SNAU. Seriia «Tvarynnytstvo». 2/2 (25), 14-20 (in Ukrainian). 
Vysokos, M.P., Milostivyj, R.V., Tjupina, N.P., Tjupina, N.V. (2014). Sostojanie zabolevaemosti i vybytija importnogo golshtinskogo skota $\mathrm{v}$ adaptacionnyj $\mathrm{i}$ posleadaptacionnyj periody $\mathrm{v}$ zavisimosti ot sposobov soderzhanija $\mathrm{v}$ stepnoj zone Ukrainy. Aktual'nye problemy intensivnogo razvitija zhivotnovodstva: sb. nauch. tr. BGSHA. Gorki. 17(2), 185-193 (in Russian).

Khmelnychyi, L.M., Vechorka, V.V. (2016). Produktyvne dovholittia dochok buhaiv-plidnykiv ukrainskoi chorno-riaboi molochnoi porody. Rozvedennia i henetyka tvaryn. 52, 134-144 (in Ukrainian).

Hmel'nichij, L.M., Vechjorka, V.V. (2016). Jeffektivnost' vlijanija genealogicheskih formirovanij na pokazateli dolgoletija i pozhiznennoj produktivnosti korov ukrainskoj cherno-pestroj molochnoj porody. Tavricheskij nauchnyj obozrevatel'. Specvypusk «Selekcionno-geneticheskie i jekologotehnologicheskie problemy povyshenija dolgoletnego produktivnogo ispol'zovanija molochnyh i mjasnyh korov». Brjanskij GAU. 5(10), 2, 23-28 (in Russian).

Endres, M. (2008). Dairy cow mortality: A growing problem. Journal of Dairy Science. 91(4), 1423-1432.

Franklyn, B.G. (2011). Adult Dairy Cow Mortality. Rezhim dostupu: http://articles.extension.org/pages/ 25469/adult-dairy-cow-mortality

Nayeri, S., Sargolzaei, M., Abo-Ismail, M.K., Miller, S., Schenkel, F., Moore, S.S., Stothard, P. (2016).
Genome-wide association study for lactation persistency, female fertility, longevity, and lifetime profit index traits in Holstein dairy cattle. Journal of Dairy Science. 100(2), 1246-1258.

Compton, C.W.R., Heuer, C., Thomsen, P.T., Carpenter, T.E., Phyn, C.V.C., McDougall, S. (2016). Invited review: A systematic literature review and metaanalysis of mortality and culling in dairy cattle. Journal of Dairy Science. 100(1), 1-16.

Murray, B. (2013). Finding the tools to achieve longevity in Canadian dairy cows. WCDS Advances in Dairy Technology. 25, 15-28.

Sewalem, A., Miglior, F., Kistemaker, G.J., Sullivan, P., Van Doormaal, B.J. (2008). Relationship Between Reproduction Traits and Functional Longevity in Canadian Dairy Cattle. J. Dairy Sci. 91, 1660-1668.

Chebel, R.C., Silva, P.R.B., Endres, M.I., Ballou, M.A., Luchterhand, K.L. (2016). Social stressors and their effects on immunity and health of periparturient dairy cows. Journal of Dairy Science. 99(4), 3217-3228.

Van Raden, P.M. (2004). Invited Review: Selection on Net Merit to Improve Lifetime Profit. J. Dairy Sci. 87(10), 3125-3131.

Van Raden, P.M., Wiggans, G.R. (1995). Productive life evaluations: Calculation, accuracy, and economic value. J. Dairy Sci. 78(3), 631-638.

Стаття надійшла до редакиії 20.02.2017 